Covenant Journal in Research \& Built Environment (CJRBE) Vol. 8 No. 1, June, 2020

ISSN: p. 2384-5724 e. 2384-5716 DOI: $\operatorname{xx\times x\times x\times x\times x\times x\times xxx}$

An Open Access Journal Available Online

\title{
Challenges and Prospects of Property Ownership in Ado-Odo/Ota Local Government Area, Ogun State, Nigeria: A Review of Literature
}

\author{
Owolabi Damilola Racheal, Ajibola Mayowa Olusola \\ \& Oluwunmi Olufunke Adedamola
}

Department of Estate Management, College of Science and Technology, Covenant University, Ota. Ogun State

folashaderac@yahoo.com

Received: 06.03.2020 Accepted: 15.05.2020

Date of Publication: June, 2020

\begin{abstract}
The aim of this paper is to identify property ownership challenges and prospects in Ado-Odo/ Ota Local Government Area, Ogun State with a view to guide property owners towards homeownership or property ownership. In the course of writing this paper, secondary data were collected from both published and unpublished journals, articles, reports, maps, and the internet was consulted to acquire more data as regards this study. Data sources are websites, government publications, books, internal records, journal articles, etc. Property ownership benefits identified include; property owner gain prestige and political power; provides shelter, health, welfare and wealth; good investment as regards to stable income generation; provides long-term monetary security; tax benefits; value appreciation overtime; provides hedge against inflation; etc. Property ownership challenges identified include; improper or lack of title document that could result to property ownership insecurity and denial to credit facilities; gender discrimination in accessing land or property; inadequate or lack of access to justice; presence of ineffective and inefficient land management system, laws and agencies; land dealings fraudulence and conflicts; poverty or lack of finance; etc. Some of the recommendations to mitigate property ownership challenges include;
\end{abstract}


government and land policymakers should ensure that laws and management system are efficient and effective, property market should be flexible for easy access to land and information, programmes should be scheduled to guard against gender discrimination as regard property ownership, law officials should ensure court proceedings are less costly and flexible for easy access to justice, etc.

Keywords: Ado-Odo/Ota, Property, Challenges and Prospects, Ogun State, Ownership,

\subsection{Introduction}

Properties are significant in reducing poverty while land is indispensable for the performance of every single human endeavor. Properties are medium for prosperity and serve as cushion against stocks. It can facilitate the arrangement of positive monetary funds accessible to people and help decide the relative dealing and basic leadership influence of individuals within the family unit (World Bank, 2012). Land does not only serve as sources of food, job opportunities, and earnings, it also offers shelter, social status and helps obtain political positions. As indicated by Emeasoba (2012), land comprises of every human, socials practices and financial dealings that lie within the core of social, political and monetary existence of major countries particularly African Nations. Land is perceived as an essential wellspring of riches, social status, power, the basis of housing, food supply, however, it is rapidly becoming a scarce asset in the urban areas. The ownership and rights of land as financial assets offer monetary security to the owner and decides the degree of participation of the owner in the society. Therefore, verifying property ownership and rights for resources is of specific significance (Emeasoba, 2012). To acquire properties, for instance, land and building enable the provision of housing to individuals. Housing is one of the fundamental human needs and certainly, have a deep effect on the wellbeing, safety, and efficiency of a person (Hoesli and MacGregor, 2014; Olujimi, 2010). The importance of housing to man cannot be overemphasized: it gives security from elements of nature and storage facility to individual belongings; lodging as per contemporary modern principles must offer such framework and administrations that make dwellings favourable (Otubu, 2008). Housing, especially urban housing remains a problematic issue in the developing nations of the world, Nigeria inclusive (Otubu, 2008). Even though the benefit to guarantee private property is frequently seen by people all through the world. Owusu (2016) stated that various researchers, law masters, and observers have included the dominance of property rights for effective improvement and advancement of the State, that is; the significance of property ownership rights is so much valued and accepted that the freedom of the citizen is insignificant in the absence of these rights (Bridge, 1973).

According to Decker (2015), property ownership often refers to ultimate residual right that has been left with 
the property owner after other property rights such as ownership have been given to others. The lawful basis for credit-based financial system essential operation, property ownership enables people to carry out financial dealings by using their property rights while holding ownership and control of their properties. Therefore, there is the need to address the absence of effective property ownership and rights that can prompt various unwanted financial outcomes for example, an absence of real property rights or ownership can prompt under investment, an absence of transferability can hinder the effective operation of the property market particularly land (Galiani, Gertler, Undurraga, Cooper, Martinez and Ross, 2017). Also, there is a need to address societies on insecure property claims or ownership that can hinder land and property being used as collaterals for loan from financial institutions (Holden, Deininger and Ghebru, 2011; Bezabih, Holden and Mannberg, 2016). Thus, the aim of this paper is to identify property ownership challenges and prospects in Ado-Odo/ Ota Local Government Area, Ogun State with a view to guide property owners towards homeownership or property ownership.

\subsection{Study Area}

Ado-Odo/ Ota Local Government Area, Ogun State is located at about 335 miles (or $538 \mathrm{~km}$ ) southwest of Ogun State. Approximately, AdoOdo/ Ota local government area occupies a land area of $878 \mathrm{~km}^{2}$ and it is described by high terrains toward the north which incline downwards toward the south. The most elevated region in the north-west which ascends more than 300 meters above the ocean level while the lowest level in the south-east ends in a long chain of tidal ponds (Ogun State Regional Plan (OSRP), 2003). The population of the area is 526,565 at the 2006 census. The male population was estimated at $260,021(49 \%)$ and female population was estimated at 266,544 (51\%) (Federal Republic of Nigeria, 2007). There is absence of inquiring why the demand for land is increasing. Preceding the time of industrialization and manufacturing activities that AdoOdo/Ota Local Government Area is known for, agribusiness was the mainstay of the economy, land is a significant product for Ado - Odo/Ota Local Government Area indigene as eighty (80) percent of land in the region are claimed by the indigenes. This is as a result of the wide range of land with few populations compared with different settlements in Nigeria. In many cases, the vast majority of the lands in the area are put forward to be purchased by the indigenes commonly called Omo onile - an informal expression for the offspring of the owner of the land-and this has become a booming economic activity.

Regardless of the huge centralization of industries besides Lagos State, the industrial expansion of Ado-Odo/Ota Local Government Area which gives business opportunities to the growing population of occupation seekers has led to high population rate and ensuing hike in costs of residential buildings and standard of living. Similarly, the increase in economic activities in the area have brought about quick 
infrastructural improvement, regarding accessibility of essential infrastructures (pipe borne water, power and good roads). The main problem of the people is the increase in demand for housing which is attended to by the establishment of government housing estates in addition to the housing estates of private developers (George and Osabuohien, 2014). Some of the popular housing estate in Ota Local Government Areas are; Muritala
Animasauwn Estate, Afobaje Estate, Ijamido Estate, Irewole Estate, Unity Estate, Oluwalogbon Estate, The living Estate, Abenis Estate, Eleidi Estate, Isokan Estate, Dalemo Estate, Ramoth Estate, Fashogbon Estate, Mission Estate, Canaan City Estate, Ogun State Housing Corporation, Government Reservation Area, Ota. Among all these areas Ogun State Housing Corporation and Government Reservation Areas are public housing estate owned by the government

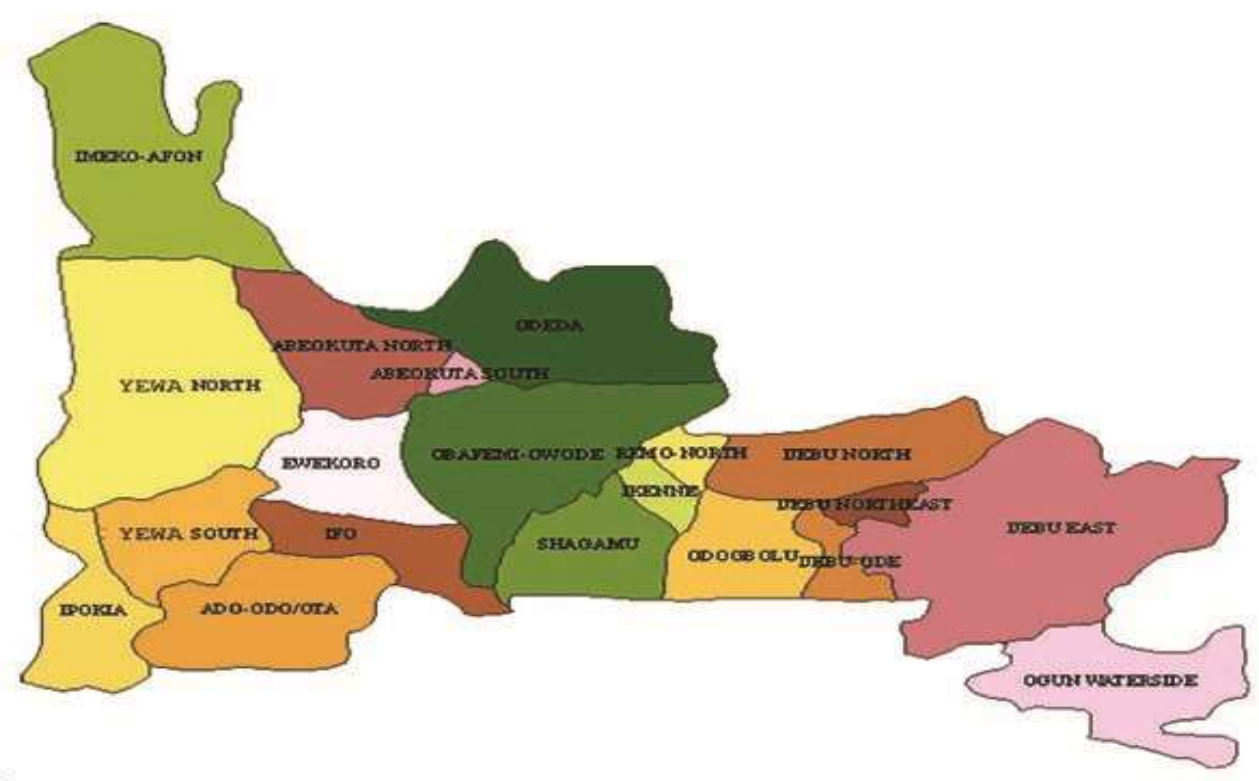

Figure 1.1: Map of Ogun State showing Ado- Odo Local Government Areas. Source: Ogun State Regional Plan (2003).

\subsection{Literature Review}

\subsection{Property Ownership Prospects}

According to Badmus, Yusuf and Ali (2017), a property is a fixed asset that is perpetual to a particular place, this could comprise land or other things constructed means that land is durable and long-lasting. Also, it may constitute things that grow or that are in existence under the surface of the land. As stated by Oyedele (2018), properties can be classified under various land uses, such as residential, industrial, commercial, recreational, educational even bare land or vacant land, etc. Generally, rights of access to these properties confer so many rights and benefits. For instance, access to land can take the form of use rights, control rights and transfer rights 
(Ostrom and Hess, 2007; Mcpeak and Little, 2019). The use right includes the right to quiet and valuable satisfaction from the property as well as the right to profit monetarily from the disposition of the property. The control rights refer to the right to eliminate others from intruding on the land. The transfer rights comprise the right put as the land for sale or mortgage or to transfer the use and control rights of land to others through intercommunity allocations and reallocations (Ostrom and Hess, 2007; Mcpeak and Little, 2019). In addition, the formation of the property market and ownership of property stock means that a property can generate capital or rental income, be disposed of in crisis circumstances or staked, gifted, or willed. Properties and land can increase in value over time, and in city regions, the property can be used as collateral to secure loans for further investment. Getting access to land is seen as a vital area of family, community, and national decision making powers (World Neighbours, 2000).

In addition, property ownership makes provision for shelter in form of housing for the property owners. According to Dovie (2019), housing is a multi-dimensional good that includes physical shelter, the associated services and substructure, and the inputs such as land and funding required to create and sustain it. Housing also provides solutions that facilitate the development of shelter and the environs in which it exists. Also, housing is a multifarious welfare commodity that enhances and facilitates the movement of other welfare commodities and facilities at the family level, causing people to be more or less reliant on the state, market, and household for the preference for other desires. The ownership of physical properties such as land and housing creates social multiplier effects. By apparently increasing owner's wealth and class positioning, they enlarge their marital prospects, political voice, and thus their business opportunities (Blomley, 2003). Also, individual own properties because it is a good investment in the sense that it commands stable or steady income in the form of rental income and capital appreciation. Depending on the location, the property can generate substantial income to pay expenses and raise funds for other purposes for the individual (Daibes, 2017).

According to Alston, Harris and Mueller (2012), land or property can be used as collateral to obtain loan or fund which can be used to meet the property owner's need (for instance; venturing in businesses, construction or alteration of property, etc.).The benefits of owning property offer individuals with long-term monetary security. The stable flow of income generated from the property, bring about monetary gains in the long run (Ivashina and Lerner, 2019). Aside from owning property to enable the productivity of an individual (Hoesli and MacGregor, 2014), economic empowerment is also gained. Agarwal (1994) states that individual land ownership facilitates the enhancements of their welfare, efficiency, and monetary empowerment and this has been 
repeated with the aid of studies established by World Bank (2015) and the United Nation Development Programme (UNDP, 2015) also stated that owning land might offer an individual purchasing power within the family, their society and large municipal places.

\subsection{Property Ownership Challenges}

Despite the various benefits derived from property ownership by different property owners, there also exist some challenges experienced by them as a result of being property owners. These challenges can result in property ownership insecurity, inaccessibility to credit facilities from financial institutions by property owners, etc. As stated by Heinsohn and Steiger (2013), even as premium on ownership forms the claim for interest, it additionally shows the willingness to own property via means of going into new contract regarding loan also consequently the disposition towards investing funds. The premiums on ownership will increase rapidly at some stages of credit crises or financial recession for instance, following an era of 'over-funding' due to an enterprise-extensive revolution phase, which includes uprisings in delivery, energy and info- technology. In-depth recessions involves relocating property ownership at instances which are enabled via momentary country ownership, bail-outs and subsidies that might also turn out to be the way out of the crisis.

In Ado-Odo/Ota Local Government Area, property owners are mainly located within informal settlements and they often lack formal land ownership documents, which weakens security of their tenure and denies them access to credit facilities (Quizon, 2017)). According to Alamanga (2018), properties without proper or formal title will command less value and their owners will have restricted tenure security. In addition, restrictions on land dealings or transactions are mainly ascribed to lack of formality in land titles rather than the existence of devious informal estate agents or unreliable properties sellers. Thus, validation of land titles in the city can therefore be of advantage to property owners, for instance, they will have unrestrictive property ownership and rights.

Gender discrimination is a challenge to land ownership, especially for the female gender. According to Anukriti (2014), female property owners are experiencing gender discrimination primarily compelled by societal views of females as economically less productive due to their restricted participation in direct incomegenerating activities and of less significant value to parents for the purpose of long-term property acquisition. Other recognized explanations behind this discrimination and denial incorporate biased customary laws, registering land in spouse's name, absence of human rights awareness and absence in implementing human rights laws and strategies. Also land ownership and inheritance laws were one of the primarily restriction for women (Bayisenge, Höjer and Espling, 2015). Within the customary and Islamic system, women may access land through their husbands (in the case of married women) or their sons (in the 
case of widows) or their dads (in the case of daughters) but can only exercise usufruct rights. In situations where women are denied their rights to property, especially land, or victimized, it turns out to be traditionally difficult for them to acquire access to bank loans or other types of credit through the financial institutions for survival since they do not have the security which banks require under the lending procedures (Hodges, 2001). In circumstance where they eventually benefit from a credit, a male guarantor is required.

Land as an asset is not been managed efficiently and effectively in the area. One of the reasons for this inefficiencies and ineffectiveness is the extent of integration between land administrative authorities, that is, there is a limited incorporation of procedures and cooperation of agencies in the management of land for housing production (Agunbiade, Rajabifard and Bennett, 2016). This has led to lack or inadequate land management policies procedure establishment which are needed for easy land accessibility and usage of land by property owners. Although acquiring land is guaranteed by the Land Use Act 1978, which specifies that all lands belong to the government, however, majority of the land dealings are carried out in informal markets under customary laws with poor or lack of certification, and documentation, administrative bottlenecks, expensive registering of land and long registration procedures, and inconsistent policy regimes impede the development and dealings within land market in Ado-Odo/Ota
Local Government Area (Oluwatayo, Timothy and Ojo, 2019).

Also, fraudulent practices are rampant in the property market dealings and are being committed via off-plan properties sales. Properties sold before finishing point (Completion) are referred to as off-plan properties and they are normally very beneficial because they are put for sale below market values. The notion of purchasing off-plan properties in AdoOdo/Ota Local Government Area has been fraught with strident practices because most of the sellers of off-plan properties fail to deliver (Gbonegun, 2018). Jacob and Onochie (2019) also view Land Use Act to have failed in its processes because there are still discriminatory practices indulged in the application of the Act that have stemmed from native-settler conflicts. The Act has been undermined by a default through which original landed families continue to apportion and exercise sales of land by backdating purchase receipts to pre- 1978 period (Babalola and Hull, 2019).

It is estimated that there is more than fifty (50) percent of Nigeria's population living in poverty. This is determined either by low income as specified by the World Bank (2012) or by Low Human Development Index as specified by the United Nation Development Programme (Akor, 2015). The implication of this is that people living in poverty in AdoOdo/Ota Local Government Area may find it difficult in owning their personal property due to the inability to raise finance to purchase or acquire such property .Carrying out land related matters or dealings by 
individuals .are very costly in terms of buying and re-selling of property, land acquisition, property development etc.

Furthermore, the problems being encountered by property owners requires the need to have collateral security and certificate of occupancy as required by most financial institutions which often is problematic for property owners in getting finance for property construction and acquisition. There is also the need for proper maintenance and management of the property in order to keep it in good shape and to retain the value of the property so as to continue generating income for the owners. As a result of this, property owners incurred high cost in maintaining and managing their property. (Hillson, Caddick, Cai, Carrasco, Chang, Curach and Gold, 2019).

According to Shetty and Luescher (2016), time is usually one of the major factors in determining the result of land dealings or transaction. The declining financial condition in AdoOdo/Ota Local Government Area is taking its toll in property ownership therefore leading to a fall in the accessibility of loanable funds for property acquisition or development. Also, due to the long gestation period in property development, most property owners and financial institutions are normally discouraged. (Oshikoya and Durosinmi-Etti, 2019)

Finally in property dealings or transactions, there is always lack of information on the fund amount that takes place, by whom, or the approaches utilised. There also exist absence of physical main point where property dealing or transactions can be conducted, since the property market varied and it is multifaceted, has an intellectual combination of distinct, isolated and uncoordinated funding that usually discourage property owners (Oshikoya and Durosinmi-Etti, 2019).

\subsection{Methodology}

In the course of writing this paper, secondary data were collected from both published and unpublished journals, articles, reports, maps, and the internet was consulted to acquire more data as regards this study. Data sources are websites, government publications, books, internal records, journal articles, etc. The secondary data used helped in identifying the existing challenges facing land ownership in the study area alongside the possibilities of having secured ownership.

\subsection{Conclusion and \\ Recommendations}

Property ownership benefits identified include; property owner gain prestige and political power; provides shelter, health, welfare and wealth; good investment as regards to stable income generation; provides long-term monetary security; tax benefits; value appreciation overtime; provides hedge against inflation; confers landlordship and decision making power on the property owner; productivity and economic empowerment and sources of food security. property ownership challenges identified include; improper or lack of title document that could result to property ownership insecurity and denial to credit facilities; gender discrimination in accessing land or property; inadequate or lack of access to justice; presence of 
ineffective and inefficient land management system, laws and agencies; land dealings fraudulence and conflicts; poverty or lack of finance; high cost of acquisition and construction of land or property; long gestation period and lack of information. Some of the recommendations to mitigate property ownership challenges includes; government and land policymakers should ensure that laws and management system are efficient and effective, property market should be flexible for easy access to land and information, programmes should be scheduled to guard against gender

\section{References}

Agarwal, B. (1994). Gender and Command over Property: A Critical Gap in Economic Analysis and Policy in South Asia. World Development, 22(10), 14551478.

Agunbiade, M. E., Rajabifard, A., \& Bennett, R. (2016). What Scope for Integrating Land Management Policies, Land Administration Processes and Data Infrastructures for Housing Production in Nigeria? Journal of Housing and the Built Environment, 31(1), 51-68.

Alananga, S. S. (2018). The Value of Formal Titles to Land In Residential Property Transactions: Evidence from Kinondoni Municipality Tanzania. International Journal of Housing Markets and Analysis, 11(1), 117-148. discrimination as regard property ownership, law officials should ensure court proceedings are less costly and flexible for easy access to justice, acquisition and validation of land title by property owners to guard them against property ownership insecurity, provision of empowerment programmes to empower and to support women in accessing land, job creation and employment to provides adequate job to people to eradicate poverty, financial institution should be more accessible and stringent requirement should be minimise to encourage people towards borrowing loans.

Alston, L. J., Harris, E., \& Mueller, B. (2012). De Facto and De Jure Property Rights: Land Settlement and Land Conflict on the Australian, Brazilian and US Frontiers (No. W15264). National Bureau of Economic Research.72, 741-770.

Akor, A. A. (2015). The Value of Political Thuggery and Violence in Nigerian Elections. The Punch, 5.

Anukriti, S. (2014). The Fertility-Sex Ratio Trade-Off: Unintended Consequences of Financial Incentives (No. 8044). IZA Discussion Paper.

Babalola, K. H., \& Hull, S. A. (2019). Examining the Land Use Act of 1978 and Its Effects on Tenure Security in Nigeria: A Case Study of Ekiti State, Nigeria. Potchefstroom Electronic Law Journal, 22, 1-34. 
Badmus, A. I., Yusuff, A. M., \& Alli,

I. A. (2017). Principles of Law. Igboora, Oyo State: Sakol Prints Ventures.

Bayisenge, J., Höjer, S., \& Espling, M. (2015). Women's Land Rights in the Context of the Land Tenure Reform in Rwanda-The Experiences of Policy Implementers. Journal of Eastern African Studies, 9(1), 74-90.

Bezabih, M., Holden, S., \& Mannberg, A. (2016). The Role of Land Certification in Reducing Gaps in Productivity between MaleAnd Female-Owned Farms In Rural Ethiopia. The Journal of Development Studies, 52(3), 360-376.

Blomley, N. (2003). Law, Property, and the Geography of Violence: The Frontier, the Survey, and the Grid. Annals of the Association of American Geographers, 93(1), 121-141.

Bridge, J. W. (1973). Fundamental Rights: A Volume of Essays to Commemorate the 50th Anniversary of the Founding Of the Law School in Exeter, 19231973. Sweet \& Maxwell

Daibes, V. (2017).Seven (7) Major Benefits of Investing in Real Estate. Retrieved from Https://Www.Mashvisor.Com/B log/Benefits-Of-Investing-InReal-Estate.

Decker, F. (2015). Property Ownership and Money: A New Synthesis. Journal of Economic Issues, 49(4), 922-946.

Dovie, D. A. (2019). Assessment Of How House Ownership Shapes
Health Outcomes In Urban

Ghana. Societies, 9(2), 43.

Emeasoba, U. R. B. (2012). Land Ownership among the Igbos of Southeast Nigeria: A Case for Women's Land Inheritance. Journal of Environmental Management and Safety, 3(1), 97-117.

Essays, UK. (2018). Ownership of Property in Islamic Law. Retrieved from Https:/Www.Ukessays.Com/Es says/Anthropology/PropertyOwnership.Php?Vref=1

Federal Republic of Nigeria (2007). Federal Republic of Nigeria Official Gazette. Retrieved from Https://Www.Cbn.Gov.Ng.

Feola, G., Suzunaga, J., Soler, J., \& Goodman, M. K. (2019). Ordinary Land Grabbing in Peri-Urban Spaces: Land Conflicts and Governance in a Small Colombian City. Geoforum, 105, 145-157.

Galiani, S., Gertler, P. J., Undurraga, R., Cooper, R., Martínez, S., \& Ross, A. (2017). Shelter from the Storm: Upgrading Housing Infrastructure in Latin American Slums. Journal of Urban Economics, 98, 187-213.

Gbonegun, V. (2018). Property Buyers

Shun Off-Plan Sales Amid Sharp Practices. The Guardian Newspaper, October 8, 2019.

George, T. O., \& Osabuohien, E. (2014).Women's Access to Land and Its Implications for Economic Empowerment in Ota, Nigeria. Retrieved from Https:/Www.Researchgate.Net/ Profile/Felicia_Olokoyo2/Public 
ation/265384676 Women's_Ac cess_To_Land_And_Its_Implic ations_For_Economic_Empowe rment_In_Ota_Nigeria/Links/54 0cd0f70cf2d8daaacaebfd.Pdf

Heinsohn, G., \& Steiger, O. (2013). Ownership Economics: on the Foundations of Interest, Money, Markets, Business Cycles and Economic Development. Routledge. Electronic Journal, 10, 2139.

Hillson, N., Caddick, M., Cai, Y., Carrasco, J. A., Chang, M. W., Curach, N. C., \& Gold, N. D. (2019). Building a Global Alliance of Bio Foundries. Nature Communications, 10(1), 2040.

Hodges, T. (2001). Children's and Women's Rights in Nigeria: A Wake-Up Call: Situation Assessment and Analysis, 2001. National Planning Commission. Retrieved from Www.Researchgate.Net/Publica tion/260186830.

Hoesli, M., \& Macgregor, B. D. (2014). Property Investment: Principles and Practice of Portfolio Management. Routledge. Retrieved from https://abdn.pure.elsevier.com/e $\mathrm{n} /$ publications/propertyinvestment-principles-andpractice-of-portfolio-manageme Holden, S. T., \& Ghebru, H. (2016). Land Tenure Reforms, Tenure Security and Food Security in Poor Agrarian Economies: Causal Linkages and Research Gaps. Global Food Security, 10, 21-28.
Holden, S. T., Deininger, K., \& Ghebru, H. (2011). Tenure Insecurity, Gender, Low-Cost Land Certification and Land Rental Market Participation in Ethiopia. The Journal of Development Studies, 47(1), 3147.

Ivashina, V., \& Lerner, J. (2019). Patient Capital: The Challenges and Promises of Long-Term Investing. Princeton University Press. Retrieved from Https://Muse.Jhu.Edu/Book/650 79

Jacob, O. O., \& Onochie, A. J. (2019). The Land Use Act of 1978: Proscription of Discrimination against Fellow Nigerians. Social Science Journal, 3, 242-252.

Mcpeak, J. G., \& Little, P. D. (2019). Land Use and Tenure Insecurity in the Dry Lands of Southern Ethiopia. The Journal of Development Studies, 55(6), 1307-1324.

Ogun State Regional Plan (OSRP), 2003. Map of Ogun State Showing Ado-Odo Local Government Areas. Retrieved from

Https://Www.Researchgate.Net/ Figure/Map-Of-Ogun-State-

Showing-The-LocalGovernments_Fig1_228671991

Olujimi, J. A. B. (2010). Analysis of the Relationships of Infrastructural Facilities in the Determination of Rental Values of Residential Properties in Akure, Nigeria. Arts and Social Sciences Journal, 2010. Retrieved from http://astonjournals.com/assj 
Oluwatayo, I. B., Timothy, O., \& Ojo, A. O. (2019). Land Acquisition and Use in Nigeria: Implications for Sustainable Food and Livelihood Security. In Land Use-Assessing the Past, Envisioning the Future. Intechopen. Retrieved from https://www.intechopen.com/bo oks/land-use-assessing-the-pastenvisioning-the-future/landacquisition-and-use-in-nigeriaimplications-for-sustainablefood-and-livelihood-security

Oshikoya, T. W., \& Durosinmi-Etti, K. (2019). Frontier Capital Markets and Investment Banking: Principles and Practice from Nigeria. Routledge. Retrieved from www.worldcat.org/title/frontiercapital-markets.

Ostrom, E., \& Hess, C. (2007). Private and common property rights. Available at SSRN 1304699.

Otubu, A. K. (2008). Housing Needs and Land Administration in Nigeria: Problems and Prospects. Land and Real Property Rights in Nigeria. Smith IO (Ed.) Faculty of Law University Of Lagos Nigeria. Retrieved from https://ssrn.com/abstract=11223 03

Owusu, A. K. (2016). Changing Face of Estate Housing Development in the Cape Coast Metropolis (Doctoral Dissertation, Department Of Geography and Regional Planning, Faculty of Social Sciences, University of Cape Coast).
Oyedele, O. A. (2018). Challenges of Investing In Real Estate in Developing Nations. Working Paper 10.13140/RG. 2.2. 10904.85766). Retrieved From Https: //Www. Researchgate. Net/Publica

Tion/328942113_Challenges_O f_Investing_In_Real_Estate_In_ Developing_Nations.

Quizon, A. B. (2017). The Continuum of Land Rights and Links to Food Security: An Overview of Community Studies from Cambodia, Nepal and the Philippines. From The Farmland to the Table. Exploring the Links between Land Tenure and Food Security. Asian NGO Coalition for Agrarian Reform and Rural Development (ANGOC).

Shetty, S., \& Luescher, A. (2016). Toledo Tomorrow: Reading Norman Bel Geddes' Vision for the Future in a Shrinking Midwestern City. Journal of Urban Design, 21(2), 177-194.

United Nations Development Programme (UNDP, 2015), Civil Society's Role in Poverty and Social Impact Analysis: A Resource Guild and Tool Kit for Engagement. Retrieved from Http://Www.Undp.Org/Poverty/ Civsoc.Htm

World Bank (2012). World

Development Report 2012:

Gender Equality and

Development. World Bank Publications

World Bank (2015) Engendering Development. Washington DC: United Nations 
